associated. The past year has seen the completion of a series of more self-contained regional library systems. Such a vast scheme of mutually supporting libraries must depend for its greatest efficiency on the maintenance of central catalogues. Union catalogues by authors of the books in the affiliated libraries are being compiled at various centres. The total number of entries in that at the National Central Library has reached million. A subjectcatalogue of books and original articles is maintained at the Science Library and has reached $2 \frac{1}{4}$ million entries. A "Union Catalogue of the Periodical Publications in the University Libraries of the British Isles" was published in 1937. The total number of books lent during that year was nearly 140,000 , of which it is significant that some 400 were supplied to foreign libraries.

\section{Prices of Biological Books in 1937}

For twelve years the Quarterly Review of Biology has analysed and compared the cost to Americans of biological books, based upon the prices of all such received for review by the Quarterly. The analyses have produced some interesting figures regarding the relative cost of books produced by different nations, and to some of them attention has been directed in NatuRE. In point of price, German books are still the most expensive, despite the announced policy of German publishers, a German average of 1.95 cents a page comparing with $1 \cdot 27$ for British books, and 0.85 for French. Than the last the only cheaper books published are those issued by the British Government $(0.34$ cents a page) and the U.S. Government $(0 \cdot 16)$, but since the last three categories are often published in paper covers, some of the saving may be on binding. Comparing 1937 with 1936 , it is remarkable to find that the average price per page from every origin, except Germany and Great Britain, has been lowered -by from about 10 per cent in U.S. books to so much as 79 per cent in British Government official publications. But while the British Government has been so greatly reducing its charges, the ordinary British publishers of biological books have been compelled to increase by 16.5 per cent. However, it is possible that the particular books received by the Quarterly for review do not represent fair samples in every case ; indeed, the total of British Government publications received in all the twelve years only amounts to 8,836 pages, so that, as the authors, Raymond Pearl and Maud DeWitt Pearl, point out, general conclusions must be drawn with caution from this material.

\section{The First Slovakian Polytechnic}

IT is true that, for a country of fifteen million inhabitants, Czechoslovakia is well provided with facilities for higher education. There are four universities, one of which is German, and numerous academies and schools of technology that grant recognized diplomas; but until now there has been no Slovak polytechnic. When the new academic year commences in October, however, this will be remedied by the opening of a polytechnic at Košice, in east Slovakia, to be named after Dr. Milan Stefaník, the
Slovak astronomer who became the first Czechoslovak Minister for War. This technical institute will rank after the Comenius University of Bratislava as the second most important educational establishment in the eastern half of the Republic. The president, Dr. E. Benež, has nominated the principal members of the staff, which will include a number of Slovaks who have graduated in science or technology. Their colleagues will be certain lecturers from the Universities and Polytechnics of Prague and Brno, and the new institute will doubtless soon be able to supply local industrial undertakings with students who have obtained their diplomas at Košice.

\section{The Public Health of India}

THE vital statistics and public health of India are dealt with in the recently published annual report of the Public Health Commissioner with the Government of India for 1935 (Vol. 1. With Appendixes. Delhi : Manager of Publications. 1937. Rs. 2, or 3s. 6d.). The mid-year estimated population was $278,199,545$, the birth-rate and the death-rate per 1,000 were respectively 35 and 24 , and the infantile death-rate per 1,000 live births was 164 (the corresponding rates for England and Wales are 15, 12 and 57). The total mortality from the three principal epidemic diseases-cholera, plague and smallpoxdecreased by 24,000 compared with 1934, but this was more than covered by the large reduction in deaths from plague, which fell from 80,000 in 1934 to 32,000 in 1935. Cholera mortality rose to 217,000 , the highest figure for the past three years. Smallpox caused 91,000 deaths, as against 84,000 in 1934 . Tuberculosis is another disease the incidence of which has increased rapidly during recent years, and which is causing a heavy mortality, particularly in urbanized and industrialized areas. Of fevers, malaria caused the heavy toll of $1,632,000$ deaths. No less than 150,000 women died in childbirth or from causes associated with childbirth. An account is also given of the public health services and administration, and of the work of the laboratories and institutes for medical research.

\section{Institution of Electrical Engineers Awards}

THE following scholarships have been awarded by the Institution of Electrical Engineers for 1938: Ferranti Scholarship (annual value $£ 250$; tenable for 2 years): L. S. Piggott (University of Oxford) ; Duddell Scholarship (annual value $£ 150$; tenable for 3 years) : J. B. Higham (Penarth County School); Silvanus Thompson Scholarship (annual value $£ 100$, plus tuition fees; tenable for 2 years): H. Darnell (Mersey Railway Company); Swan Memorial Scholar. ship (annual value $£ 120$; tenable for 1 year): J. G. Hutton (Sunderland Technical College); David Hughes Scholarship (value $£ 100$; tenable for 1 year): H. E. Newton (University of Sheffield); Salomons Scholarship (value $£ 100$; tenable for 1 year): C. Halliday (King's College, Newcastle-on-Tyne). Grants have been made from the War Thanksgiving Education and Research Fund (No. 1) to J. W. Carroll (King's College, London), to E. Franklin (University of Birmingham), and to G. Y. Shute (University 